Boža Krakar Vogel ${ }^{1}$

Filozofska fakulteta Ljubljana

https://doi.org/10.18485/mks_knsjkk.2017.ch4

\section{SPREMEMBE V SLOVENSKEM SREDNJEŠOLSKEM POUKU KNJIŽEVNOSTI V ZADNJIH DESETLETJIH}

Opisujemo ključne spremembe v teoriji in v kurikulu književnega pouka v desetletju pred osamosvojitvijo in po njej do sodobnosti. Pokažemo potek sprememb, od vsebinske ideologizacije in pozitivistične reprodukcije $\mathrm{k}$ intenzivnejši metodi interpretacije in komunikacijskega pouka, nato pa k pouku književnosti po načelih sistemske didaktike. Spremembe književnega pouka prikazujemo v povezavi z družbenimi in kurikularnimi spremembami v šolskem sistemu, ki so intonirale splošne okvire. Prikazani so tudi nekateri učinki aktualnega književnega pouka pri dijakih.

Ključne besede: reproduktivni pouk, eksterna matura, komunikacijski pouk, sistemska didaktika književnosti.

\section{Uvod}

Pouk književnosti velja v Sloveniji za družbeno občutljivo področje, posebno na gimnazijski stopnji. Razlog je v vlogi, ki jo je književnost imela v slovenski zgodovini. Podobno kot to velja za narode, ki v preteklosti niso imeli lastne države, je tudi pri nas kultura, posebno jezik in književnost, imela vlogo konstitutivnega elementa, ob katerem se je v tradiciji najbolj oblikovala slovenska nacionalna identiteta. ${ }^{2}$ Tudi v sodobnosti, ko so to nalogo prevzeli drugi atributi državnosti, se ob kurikularnih spremembah na tem področju javnost pogosto intenzivno odziva in pokaže, kakšne so pri nas predstave o tem, kaj naj bi izvedeli bodoči izobraženci oz. katere so prednostne vzgojno izobraževalne naloge književnega pouka, in kaj vanj ne sodi. Ta, velikokrat nasprotujoča si mnenja so opozorilo, da morajo biti načrtovalci pouka materinščine pazljivi bolj kakor snovalci drugih predmetov in da poleg strokovne nosijo tudi precejšnjo družbeno in celo moralno odgovor-

\footnotetext{
${ }^{1}$ boza.krakar@guest.arnes.si

2 „Slovenci v okviru Avstrije oziroma Avstro-Ogrske pa tega (ustanovitve države, op. BKV) seveda tedaj nismo mogli uresničiti, zato smo svoje želje po samobitnosti sublimirali v kulturo in skoz kulturo, še posebej pesništvo« (Pirjevec 1978).
}

nost. Ker pa je obe slednji težko prevzemati brez temeljitih strokovnih podlag in argumentov o razlogih in učinkih posameznih rešitev, bomo $\mathrm{v}$ članku govorili predvsem o strokovno teoretičnih vidikih oz. paradigmah književnega pouka, kot so se razvijali v zadnjih nekaj desetletjih pri tem pa se sproti dotikali tudi pedagoške prakse in javnih odzivov.

\section{Burna 80. leta}

V političnem pogledu je bil to še čas skupne države, Jugoslavije po Titovi smrti, ko so se na eni strani kazale težnje nacionalnih osamosvajanj, na drugi pa težnje po centraliziranem delovanju države, torej tudi izobraževalnega sistema. Tako naj bi se v šolstvu sredi 80. let uvedla t.i. skupna jedra, enotne vsebine za določene šolske programe po celi Jugoslaviji. To je pomenilo, naj bi dijaki v Srbiji, Sloveniji, Makedoniji idr. spoznali enako število avtorjev iz svoje nacionalne kulture kakor iz drugih republik z območja Jugoslavije ( približno po deset iz vsake). Ker bi tako ne bilo dovolj priložnosti za prednostno spoznavanje razvoja in vloge lastne nacionalne književnosti, kulture in obenem temeljev nacionalne identitete, saj bi bile vse literature ponujene $\mathrm{v}$ enaki mešanici vsem jugoslovanskim dijakom iz skupnega talilnega lonca, so se posamezni narodi temu uprli in projekt skupnih jeder je usahnil. ${ }^{3}$

V Sloveniji so v tem času mimo »skupnih jeder« potekale tudi razprave in polemike o tedanjem nezadovoljivem pouku književnosti, ki je v praksi pretežno potekal kot pozitivistično spoznavanje literarno zgodovinskih kontekstualnih dejstev, branja literarnih besedil pa se dijaki niso naučili. Kritiki so čedalje bolj argumentirano zahtevali zmanjšanje obsega faktografije in pojačenje dejavnega branja pri pouku. V osemdesetih letih so se že pojavljala poročila nekaterih učiteljev o tovrstnih izkušnjah, a so bila kljub poskusom splošne implementacije v reformi usmerjenega izobraževanja redka. ${ }^{4}$

\footnotetext{
${ }^{3}$ O tem več v avtobiografskem romanu Cirila Zlobca Spomin kot zgodba (1998).

${ }^{4}$ Reforma usmerjenega srednjega izobraževanja (izobraževalni programi so že usmerjali v določene poklice) je bila vpeljana v Jugoslaviji v začetku 80. let. Slovenski snovalci književnega pouka so ob njej poskušali zmanjšati faktografijo in uvesti več interpretacije, vendar je bil poskus didaktično in idejno premalo osmišljen, kar je bil dodaten razlog za javne kritike v 80. letih.
} 
Vse te javne debate ob usmerjenem izobraževanju, skupnih jedrih in didaktični neustreznosti obstoječe prakse so imele z didaktičnega vidika skupni imenovalec $v$ tem, da se je zahteva po vzgoji bralne kulture pri dijakih, dosegljiv z dejavnim branjem in interpretacijo literarnih besedil pri pouku izkristalizirala kot osrednji cilj književnega pouka.

\section{Uvedba eksterne mature}

Eksterna matura ${ }^{5}$ je bila v slovenski šolski sistem uvedena 1. 1995, štiri leta po slovenski osamosvojitvi in tri leta pred uvedbo celostne šolske reforme, kurikularne prenove. V šolskem sistemu se je torej začela streha prenavljati pred temelji. A ker so se snovalci koncepta izpita iz slovenščine zavedali njegovega vpliva na nadaljnji učni proces, so kljub aktualni pretežno pozitivistični poučevalni praksi književni del izpita ${ }^{6}$ oblikovali tako, da je od maturantov zahteval pisanje eseja na književno temo - kot dokaz sposobnosti branja, interpretacije in izražanja o književnosti. Esej je pomenil precejšnjo novost, ki je tudi sprožila ogorčene javne odzive. Kritičnost je zadevala poimenovanje besedilne vrste (esej so mnogi razumeli kot literarno formo, ne kot šolsko besedilo). Nerazumevanje je letelo tudi na poseben sklop literarnih besedil, ki jih morajo maturanti prebrati v zadnjem letu kot podlago za pisanje, a so pogosto nesprejemljiva za del javnosti. ${ }^{7} \mathrm{Ne}$

\footnotetext{
${ }^{5}$ Eksterni maturitetni izpit pripravljajo in ocenjujejo zunanji eksperti, imenovani od ministrstva. To naj bi zagotovilo enoten izobrazbeni standard na določeni šolski stopnji. Hkrati je matura tudi vstopnica za univerzo, kjer posamezne fakultete določijo kot pogoj število točk, ki jih zbere kandidat pri petih maturitetnih predmetih. Sprejemni izpiti so ostali na nekaterih umetniških fakultetah oz. na šolah s specialnimi zahtevami.

${ }^{6}$ Izpit iz materinščine je sestavljen iz pisnega jezikovnega testa ( $30 \%$ ocene) in književnega dela (esej, $50 \%$ ocene) in iz ustnega izpita (20\% skupne ocene - več v Predmetnem izpitnem katalogu, gl. Enoto v Bibliografijo na koncu prispevka). Kandidat pri izpitu lahko skupaj doseže 8 točk, kolikor pri drugih predmetih lahko doseže le, če jih opravlja na višji ravni (sicer pa le 5 točk). Z možnostjo, da vsak kandidat lahko pridobi 8 točk, brez nivojske diferenciacije, je materinščini zaenkrat priznan poseben status. - Vendar so težnje v delu pedagoške javnosti, da se tudi pri materinščini uvedeta dva nivoja izpita, češ da je tak poseben status slovenščine »nacionalistično ideološki «).

${ }^{7}$ V I. 2017 sta bila obvezno maturitetno branje dva romana: Alamut Vladimirja Bartola in Krasni novi svet Aldousa Huxleya. Nekateri, mdr. filozof Mladen Dolar, so kritiziral predvsem izbiro Alamuta, češ da nima literarne vrednosti. Vihar je sprožil tudi naslov za esej: Samomor kot izstop iz represivnega sistema.
}

glede na takšne odzive pa je nova zasnova mature sprožila intenzivnejši komunikacijski pouk literature, ki je celostno kurikularno podlago dobil nekaj let kasneje, z uveljavitvijo kurikularne prenove, prve celostne šolske reforme v samostojni Sloveniji.

\section{Kurikularna prenova}

Prva celostna reforma šolskega sistema v novi državi je potekala od 1995 do 1998, novi učni načrti pa so začeli veljati 1998/99. Poglavitna sprememba je bila uvedba devetletne osnovne šole, v pedagoško didaktičnemsmislu pa še poudarek na funkcionalnih ciljih, uporabnem znanju ter razbremenitev vsebin v učnih načrtih. ${ }^{8}$

Učni načrti za pouk materinščine/književnosti so šele zdaj oblikovali celostne didaktične podlage za komunikacijski pristop, ki se je poprej izvajal le deloma in pod vplivom mature.

Kot temeljna metoda za uresničevanje tega cilja je bila priporočena šolska interpretacija v sistemu sedmih faz (Krakar Vogel 1991, 2004).

Spremenil se je tudi nabor vsebin oz. predpisan/priporočen seznam literarnih del, med katerimi so bile nekatere enote izbirne, saj je bil skupni obseg vsebin zmanjšan zaradi časa, predvidenega za dejavno sodelovanje učencev. ${ }^{9}$ Spremenil se je tudi kriterij uvrščanja literarnih vsebin. V jugoslovanski državi je bilo 60\% vsebin (avtorjev in del) iz slovenske književnosti, po $20 \%$ pa iz jugoslovanskih in iz svetovne književnosti. Z reformo pa je sklop jugoslovanskih književnosti odpadel, nekatera besedila pa so bila uvrščena v sklop svetovne literature (zdaj 40\% vsebin). V spodnji tabeli je prikazano, kako so od prenove dalje $\mathrm{v}$ okviru svetovne književnosti zastopane $\mathrm{v}$ dveh sestavih beril posamezne slovanske literature. (Ambrož, D. i dr. 2008, 2009, 2010; Blažić, M. i dr. 2014, 2015, 2016).

\footnotetext{
${ }^{8} \mathrm{~V}$ projektu je sodelovalo več kot 500 strokovnjakov za različna področja, piramidalno organiziranih po predmetnih komisijah in komisijah za vzgojno izobraževalne programe. Že pred uvedbo in po njej je bila vrsta razprav in seminarjev za učitelje, okroglih miz in medijskih predstavitev.

9 Z longitudinalno empirično raziskavo smo ugotovili, da je minimum za povprečno obravnavo besedila 2-3 ure - poseben projekt pod mojim vodstvom pri ZRSŠ med 1992 in 1996, pri katerem je skupina učiteljev natančno poročala o didaktičnih in časovnih obravnavah besedil od 1. do 4. letnika.
} 


\begin{tabular}{|c|c|c|c|c|c|}
\hline Ruska KN & $\begin{array}{c}\text { Ceška } \\
\text { KN }\end{array}$ & $\begin{array}{c}\text { Srbska } \\
\text { KN }\end{array}$ & $\begin{array}{l}\text { Hrv. } \\
\text { KN }\end{array}$ & Polj. KN & $\begin{array}{l}\text { Slovaška, } \\
\text { mak. KN }\end{array}$ \\
\hline $\begin{array}{l}\text { Pesem o } \\
\text { Igorjevem } \\
\text { poh., } \\
\text { Belinski, } \\
\text { Dostojevski, } \\
\text { Tolstoj, } \\
\text { Turgenjev, } \\
\text { Čehov, } \\
\text { Brodski, } \\
\text { Blok, } \\
\text { Majakovski, } \\
\text { Jesenin, } \\
\text { Pasternak, } \\
\text { Cvetajeva, } \\
\text { Bulgakov, } \\
\text { Zamjatin } \\
\text { Oš: Krilov, } \\
\text { Tolstoj, } \\
\text { Gogolj, } \\
\text { Puškin }\end{array}$ & $\begin{array}{l}\text { Macha, } \\
\text { Hašek, } \\
\text { Kundera }\end{array}$ & $\begin{array}{l}\text { Njegoš, } \\
\text { Andrič }\end{array}$ & $\begin{array}{l}\text { H. } \\
\text { Lucič, } \\
\text { Držić, } \\
\text { Krleža }\end{array}$ & $\begin{array}{l}\text { Kochanowski, } \\
\text { Mickiewicz } \\
\text { Szymborska }\end{array}$ & Janovic \\
\hline
\end{tabular}

Poglavitno načelo razvrstitve vsebin za gimnazije pa je kljub prevladujočim načelom recepcijske didaktike ostalo tradicionalno literarno zgodovinsko, z nekaterimi medbesedilnimi ekskurzi v sodobno književnost ${ }^{10}$ (vidno v učnem načrtu, gl. bibliografsko enoto v Bibliografiji).

\subsection{Recepcijsko komunikacijska didaktika književnosti}

Specialno didaktična doktrina, na kateri temeljijo učni načrti za slovenščino v osnovnih in srednjih šolah v času kurikularne prenove, je komunikacijski pouk. Temelji na pedagoških načelih »na učenca osredinjenega pouka« oz. učenčeve dejavne komunikacije z učno vsebino, čemur na področju književnosti ustrezajo literarnovedna spoznanja teorije odziva in teorije recepcije. Zato to poučevalno paradigmo imenujemo tudi recepcijsko komunikacijska didaktika književnosti (Krakar Vogel, Blažić 2013).

Uspešnost pouka je po načelih recepcijske didaktike odvisna od upoštevanja bralčevih pričakovanj, ki naj se jim prilagaja izbira besedil,

${ }^{10}$ Učni načrt za gimnazije iz l. 1998, gl. Bibliografijo. ter metode pouka - v sistemu šolske interpretacije je posebej poudarjena uspešna motivacija, doživljajski pogovor, druge oblike opisnega in ustvarjalnega izražanja (pisanje, likovno ustvarjanje, uprizarjanje, uglasbitve, multimedijski projekti z izrabo računalniške tehnologije).

Učinki oz. cilji takega pouka se uresničijo v motiviranem bralcu, ki zaradi pozitivnih izkušenj z branjem rad posega po branju tudi sam in ob prostem času.

Za boljše zaznavanje literarnoestetskih prvin $\mathrm{v}$ branih besedilih bralec sicer potrebuje nekaj literarnega znanja, tj. literarne teorije in zgodovine, vendar je to $\mathrm{v}$ funkciji širjenja obzorja pričakovanj. Nadgrajevanje uporabnega literarnega znanja, potrebnega za razmišljujoče opazovanje besedila v sistemsko znanje (tj. umeščanje spoznanih prvin v hierarhično strukturo pojmovnih kategorij, npr. literarno morfoloških ali literarno razvojnih) ni cilj pouka $\mathrm{v}$ paradigmi recepcijsko komunikacijske didaktike. Zato je v času kurikularne prenove bila tudi za srednje šole močna težnja po redukciji sistemskega kontekstnega literarnega znanja (literarne in kulturne zgodovine), pač z namenom, razbremeniti učence faktografije, ki da jemlje prostor literarno estetski komunikaciji: »Izbor besedil torej ne izhaja več iz literarnozgodovinskega opredeljevanja pomena kakega besedila [...] učitelj pa ne posreduje več tuje učenosti v želji po doseganju čim večje literarne razgledanosti učencev« (Saksida 2003:104). Oziroma: »Pouk branja in dejansko spodbujanje in usvajanje bralne zmožnosti terjata izredno intenzivno in dolgotrajno delo $\mathrm{z}$ besedili [...], zato pri tako naravnanem pouku navadno ne bi smeli izgubljati časa s prekomernimi podatki iz literarne zgodovine in imeni avtorjev« (Grosman 2004: 32). Čeprav je, kot rečeno, razporeditev avtorjev in besedil za srednje šole ostala literarnozgodovinska, je bil kontekst okrnjen na najnujnejše, osrednja dejavnost pri pouku pa poglobljena interpretacija predpisanih literarnih besedil.

\section{Posodobitvena reforma}

Ker so se v desetih letih pokazale nekatere pomanjkljivosti pri uvedenih novostih in potrebe po nekaterih spremembah, se je oblast 2008 odločila za sicer manj korenito »posodobitveno reformo«.

Smernice za spremembe pri gimnazijskem književnem pouku so nakazovali rezultati raziskav (Ivšek 2007, Poznanovič Jezeršek 2008), 
praktične izkušnje, pa tudi novosti v pedagoških pristopih, usmerjenih v razvijanje ključnih zmožnosti. ${ }^{11}$ Pokazala se je šibka literarna, splošna kulturna razgledanost in odsotnost zgodovinske perspektive pri dijakih. Zato je bila v prenovljenem učnem načrtu za gimnazije spet bolj poudarjena vloga literarno- in kulturnozgodovinskih vsebin, tj. umeščanje posameznih interpretiranih besedil $v$ literarni sistem ter ugotavljanje in vrednotenje vloge literature kot dela kulturnega in družbenega življenja v sodobnosti in preteklosti.

\subsection{Sistemsko komunikacijska didaktika književnosti}

Nakazane spremembe temeljijo na načelih druge literarno didaktične usmeritve, imenovane zaradi opiranja na sistemske teorije literature sistemska didaktika književnosti. V tej se pouk literature pojmuje kot spoznavanje teksta v kontekstu. ${ }^{12}$ Pouk za razvito bralno in književno kulturo na višji ravni po tem pojmovanju vključuje tako branje in interpretacijo (doživljanje, razumevanje, vrednotenje) posameznih literarnih besedil kakor tudi sistematično spoznavanje in razumevanje dejavnikov literarnega in kulturnega konteksta (avtorja, dobe, recepcije pri bralcih ipd.) v slovenskem in mednarodnem okolju v sodobnosti in preteklosti. Kontekstna razgledanost nudi učencu referenčni okvir za ustvarjanje predstav o povezanosti posameznega v sklop širšega literarnega, družbeno-, kulturno- in duhovnozgodovinskega dogajanja ter za priklic informacij pri novem branju in refleksiji novih literarno-kulturnih pojavov (po Krakar Vogel, Blažič 2013). Zato je šolska interpretacija zastavljena tako, da prek doživljajsko problemske obravnave besedil (kaj in kako je napisano) vodi učence k umeščanju posameznih besedil v kontekst oz. $\mathrm{v}$ literarni sistem ter $\mathrm{k}$ sistematičnemu razvijanju ključnih zmožnosti kot čezpredmetnih ciljev.

\footnotetext{
${ }^{11}$ Ključne zmožnosti/kompetence so kompleksi znanj, sposobnosti in stališč, ki tvorijo posameznikovo usposobljenost na ključnih področjih življenja in dela. Dokument Deseco (gl. Bibliovrafijo ) jih našteva osem, mdr. sporazumevanje v maternem in tujih jezikih, kulturno zavest ... Pridobivajo se $\mathrm{z}$ medsebojnim povezovanjem pri različnih šolskih predmetih in sestavljajo t.i. čezpredmetne /kroskurikularne cilje.

${ }^{12}$ Sistemsko teorijo literature obsežno prikazuje Marjan Dović (2004). Citira tudi enega od poglavitnih akterjev v Nemčiji, Siegfrieda J. Schmidta, ki za pouk literature pravi "Namesto da bi besedila le interpretirali, je smiselno preučevati vse štiri delovalne vloge« (Dović 2004: 86).
}

- Ponovni močnejši poudarki na kontekstu torej niso enaki kakor pri tradicionalnem dogmatsko reproduktivnem pouku, ko je bila dijakova interpretacija besedila s ciljem vzgoje bralne sposobnosti obrobna ali zapostavljena dejavnost (Rosandić 2005).V sistemski paradigmi velja, da se kontekst povezuje z večplastnim branjem besedil, njihovo primerjanje, umeščanje in aktualizacija pa temelji na dijakovem dejavnem sodelovanju.

Na osnovi zgornjega opisa je na vprašanje, ki se je zastavljalo v času kurikularne prenove, ali naj pouk književnosti na celotni šolski vertikali poteka po eni literarnodidaktični (recepcijsko komunikacijski) paradigmi, mogoče odgovoriti nikalno. Stopnjo bralne sposobnosti ter bralne in književne kulture, pa odnosa do literature kot posebne oblike družbenega delovanja, je v šolskem sistemu potrebno nadgrajevati. Zato je bolj smiselno oblikovati diferencirana uporabna načela, kar je deloma že izpeljano v praksi: sistemskodidaktični paradigmi se najbolj približuje pouk književnosti v gimnazijah, recepcijski paradigmi pa v osnovni šoli. V drugih programih gre za ustrezne kombinacije didkatičnostrukturnih prvin (Krakar Vogel, Blažič 2013). ${ }^{13}$

\section{Učinki v praksi in nekaj misli o nadaljnjih smernicah}

Učni načrti iz l. 2008 so še v veljavi. V zadnjih letih smo z empiričnimi raziskavami ugotavljali tudi praktične učinke didaktičnih usmeritev na znanje in stališča učencev in učiteljev.

Prvi in drugi se ocenjujejo zelo dobro: učitelji svoj trud za razvijanje znanja, sposobnosti in vrednot pri dijakih kar z oceno 4,5 , učenci

\footnotetext{
${ }^{13}$ Temeljni cilji v osrednjih šolskih programih so v navedeni publikaciji formulirani takole: gimnazija: vzgoja kultiviranega bralca (bere različne zvrsti slovenske in tuje literature, pozornost posveča vsebini in obliki, ima razgled po literarnem sistemu, razvito kulturno zavest idr. socialno personalne zmožnosti); osnovna šola vzgaja motiviranega bralca, t.j. ga motivira in senzibilizira za estetsko, moralno in socialno doživljanje zanj ustreznih besedil; podoben namen ima pouk književnosti $\mathrm{v}$ dve- in triletnih poklicnih šolah, $\mathrm{z}$ didaktičnimi in vsebinskimi prilagoditvami razvoju dijakov; $v$ štiriletnih srednjih šolah (za ekonomske, zdravstvene, strojne idr. tehnike, ki gredo lahko tudi na univerzo) se vzgaja razmišljujoči bralec, ki ob branju razmišlja o pomembnih socialnih, moralnih, osebnih problemih in je bolj kot na obliko pozoren na vsebino. Kot sistem naj bi spoznaval predvsem slovensko književnost ter nekatera besedila iz svetovne. - Ključne književne in kulturne pojave skozi čas (npr. reformacijo, Prešerna, Cankarja itn.) pa naj bi ustrezno prilagojeno spoznavali v zaključnih letnikih tudi učenci osnovnih in poklicnih šol.
} 
pa s 3,5 na petstopenjski lestvici. Podrobnejši pregled rezultatov testa znanja, ki so ga dijaki v raziskavi reševali v prvem in tretjem letniku gimnazije ob Prešernovi Glosi, pa je pokazal le slabo dvojko! Dijaki so v vprašalniku sicer odgovarjali npr., da na splošno prepoznavajo stilna sredstva v besedilu ali da ga znajo pretvoriti v "prozo« ipd., v konkretnem primeru pa ni šlo tako zlahka. Kar tretjina jih namreč v testu ni napisala kratke obnove pesmi, tudi kulturno zgodovinskih pojmov v njej ni poznala ipd. (Jožef Beg 2015).

Dijaki sami ob prostem času ne berejo radi. Odgovarjajo, da nimajo časa in da jih branje ne zanima, pa da je prenaporno. Književni pouk se jim zdi dolgoročno »koristen« predvsem kot priložnost za boljše izražanje, za splošno razgledanost, za aktualizacijo izkušenj. Dosti manj pa zaznavajo književni pouk kot pot do koristnega razmišljujočega in kritičnega branja, razvijanje kulturne ali domovinske zavesti, možnosti za učenje učenja ali za kakovostno uporabo novih tehnologij (v njih se sicer zelo dobro znajdejo, vendar jih pri pouku slovenščine ne uporabljajo in jih tudi ne pogrešajo) - prav tam. - Na nekatere od naštetih sestavin so slabo pozorni tudi učitelji, npr. razvijanje domovinske zavesti je po osamosvojitvi zelo upadlo, medtem ko se je povečala senzibilizacija za socialno občutljivost, medkulturnost idr. Prav tako so pri pouku slabo prisotni mnogi elementi razvijanja kulturne zavesti (npr. kupovanje knjig, ustvarjanje domače knjižnice idr. ) - Šebjanič Oražem 2016.

Vseeno pa dijaki mnoge elemente književnega pouka ocenjujejo tudi pozitivno. Radi sodelujejo pri zanimivih urah iz književnosti in berejo ter razpravljajo pri pouku (Krakar Vogel 2014). Ob vsej kritičnosti zaznavajo tudi pozitivne učinke mature: pri pripravah na esej pridobijo zmožnost branja literature in razpravljanja o prebranem ter zmožnost razumevanja in tvorjenja besedil. ${ }^{14}$

Tu zapisano želi pokazati, da spremembe književnega pouka potekajo skozi zadnja desetletja na strokovnih temeljih in da vodijo postopoma v kompleksno, raziskovalno in z izkušnjami podprto sodobno

\footnotetext{
${ }^{14}$ Učinke maturitetnega izpita za bivše maturante (sodelovalo je prek 1000 brucev različ nih fakultet) in učitelje (preko 300) smo 1.2016 raziskovali v delovni skupini prostovoljcev pri Slavističnem društvu Slovenije. Rezultate je zbral Državni izpitni center v aprilu 2017.
} Slavistično društvo Slovenije bo o tej temi v jeseni 2017 organiziralo poseben posvet. komunikacijo med učencem in literaturo. Poleg javno bolj razvpitih negativnih dajejo tudi pozitivne učinke, ki jih prepoznavajo tudi »uporabniki«, učitelji in dijaki. Dejstvo, da niso vedno in vsi na zaželeni stopnji, bi težko pripisali zgolj pomanjkljivi didaktični teoriji in praksi, pa naj gre za izbiranje vsebin, metod ali za delo učiteljev, ki so zdaj mnogo bolje usposobljeni kot pred desetletji. Mnogo na vrednotenje književnosti vplivajo tudi splošne aktualne razmere, ti. duh časa, ki marginalizira humanistiko in zahtevno ukvarjanje $\mathrm{z}$ besedili, ki ne prinašajo hitrih in neposrednih informacij, koristi ali zabave. Tem globalističnim antihumanističnim procesom je v sodobnem svetu antipod prav književnost, ki je mladim generacijam ne glede na kritike najbolj kompleksno ponujena prav pri pouku. Zato kaže dosedanje ugotovitve in argumente o dopolnjujočih se didaktičnih paradigmah in diferenciranih pristopih nadgrajevati in razvijati. Podleganje parcialnim subjektivnim pogledom in nedozorelim didaktičnim ekskluzivizmom se po izkušnjah iz preteklosti dolgoročno ne obnese. Mlade to še bolj kot zahtevni spoznavni postopki oddaljuje od kompleksne narave literature in možnosti za identifikacijo z vsaj katerim od njenih segmentov. Včasih je bilo tako oddaljevanje posledica težnje po literarni vzgoji v imenu krščanske ali komunistične ideologije, v prihodnosti bo nemara zaradi ideologije liberalizma in digitalizacije. Zlasti na šolskem polju velja paziti, da se ne bi specifike literarne komunikacije izgubile $v$ digitalno komunikacijskem talilnem loncu, ki v duhu »znanja za prihodnost« daje prednost tehnologiji pred vsebino, površni komunikaciji pred estetsko in etično senzibilizacijo in kar je še prav prek literature drugih dosegljivih pogojev za bralno pismenost in druge ključne kompetence posameznika.

\section{CITIRANA LITERATURA}

Ambrož, D. i dr. Branja 1, 2, 3, 4.: Berilo in učbenik za pouk književnosti v gimnazijah. Ljubljana: DZS, 2008, 2009, 2010;

Blažić, M. i dr. Novi svet iz besed 7, 8, 9. Učbeniki za pouk književnosti v 7., 8., 9. razredu devetletne osnovne šole. Ljubljana: Rokus-Klett, 2014, 2015, 2016.

Dović, M. Sistemske in empirične obravnave literature. Ljubljana: Založba ZRC, 2004. 
Grosman, M. Zagovor branja. Ljubljana: Sophia, 2004.

Ivšek, M. (ur.) Razmerje med razvijanjem in vrednotenjem sporazumevalne zmožnosti. CRP. Razvojno-raziskovalni projekt 2004-2006. Sklepno poročilo. Ljubljana: ZRSŠ, 2007.

Jožef Beg, J. Razvijanje ključnih zmožnosti pri pouku književnosti v gimnazijah. Doktorska disertacija. Ljubljana: Filozofska fakulteta, 2015.

Krakar Vogel, B 1995/96: »Pouk književnosti v srednji šoli.« Jezik in slovstvo, letn. 41, št.1-2 (nov., 1995/96): 51-60.

Krakar Vogel, B. Skice za književno didaktiko. Ljubljana: Zavod RS za šolstvo, 1991.

Krakar Vogel, B. Poglavja iz didaktike književnosti. Ljubljana: DZS, 2004. Krakar Vogel, B., Milena Mileva Blažić Sistemska didaktika književnosti $v$ teoriji in praksi. Ljubljana: Pedagoški inštitut, 2013.

Literary Framework for Teachers in Secondary Education, (2012). http://www. literaryframework. eu. (dostop 27. 8. 2014). 1978.

Pirjevec, D. Vprašanje o poeziji, vprašanje naroda. Maribor: Obzorja,

Predmetni izpitni katalog za splošno maturo 2017 - slovenščina ... www. ric.si/splosna_matura/predmeti/slovenscina/. Dostop 21. 5. 2017.

Rosandić, D. Metodika književnoga odgoja. Zagreb: Školska knjiga, 2005.

Saksida, I. »Komunikacijski pouk književnosti v osnovni šoli.« Slovenski jezik, literatura in kultura v izobraževanju. 39. seminar slovenskega jezika literature in kulture (2003). Boža Krakar Vogel (ur.). Ljubljana: Filozofska fakulteta: 93-108.

UČNI NAČRT. SLOVENŠČINA. Gimnazija. Splošna, klasična, strokovna gimnazija. Obvezni ... učnega načrta za predmet slovenščina v gimnazijah iz leta 1998. Www.mss.gov.si/fileadmin/mss.gov.si/.../Gimnazije/UN_SLOVENSCINA_gimn.pdf (Dostop 5.9. 2017)

UN_SLOVENSCINA_gimn.pdf.www.mss.gov.si/fileadmin/mss.gov.si/.../ ss/.../2008/... (Dostop 5. 9. 2017).

Virk, T. Moderne metode literarne vede in njihove filozofsko-teoretske osnove. Ljubljana: Filozofska fakulteta, 1999.

Zlobac, C. Spomin kot zgodba. Ljubljana: Prešernova družba, 1998.

\section{ИЗМЕНЕНИЯ В ПРОВЕДЕНИИ УРОКОВ ЛИТЕРАТУРЫ В}

\section{СЛОВЕНСКИХ СРЕДНИХ ШКОЛАХ ЗА ПОСЛЕДНИЕ ДЕСЯТИЛЕТИЯ}

В статье описываются ключевые изменения в теории и в куррикулуме уроков литературы перед провозглашением независимости и после него. Прослеживается ход изменений от идеологизации содержания и репродукции в духе позитивизма к более интенсивной интерпретационной и коммуникативной методике, а затем к преподаванию литературы по дидактическим принципам системного подхода. Изменения методики преподавания литературы показаны в связи с общественными изменениями и изменениями общеобразовательной школьной программы, которые повлияли на общие рамки проведения занятий. Приводятся также результаты влияния современных уроков литературы на учеников средних школ. 